\title{
Pieśń kaleka. Reka Bolesława Leśmiana w kontekście poezji ekspresjonistycznej
}

Reka to czwarty, zarazem przedostatni utwór krótkiego cyklu poetyckiego Bolesława Leśmiana zatytułowanego Pieśni kalekujace (z tomu Łąka, 1920). Jego miejsce w obrębie tej niewielkiej całostki kompozycyjnej jest szczególne. $\mathrm{Z}$ jednej strony, łatwo odnaleźć w nim element tematyczny, który stanowi o spójności cyklu. Owym wspólnym dla pięciu wierszy mianownikiem jest istnienie najdosłowniej „kalekie” - niepełne (w wierszu $Z a-$ loty jego ikoną jest „nędzarz bez nóg”, w Szewczyku tytułowy „szewczyk-kuternoga”, w Żotnierzu wojak, którego kula uczyniła „bardzo koślawym”) lub też nadmiernie rozrośnięte, wybujałe ponad miarę i w swej biologiczności groźne (garb noszony na plecach przez bohatera wiersza Garbus). W liryku Reka mamy do czynienia z wariantem drugim: tytułowa kończyna olbrzymieje do nadnaturalnych rozmiarów, staje się tworem niezależnym od osoby, do której ciała pierwotnie przynależała. Taki dobór bohaterów sprawia, że wszystkie wiersze cyklu mają (w mniejszym lub większym stopniu) cechy groteski ${ }^{\mathrm{I}}$.

Z drugiej strony, wiersz Reka już w pierwszej lekturze odróżnia się od pozostałych Pieśni kalekujacych - i to z kilku powodów. Po pierwsze, w Receinna jest - nazwijmy to na razie bardzo ogólnie - perspektywa nadawcza: $w$ wierszu tym zarysowany został podmiot mówiący uczestniczący w zdarzeniach, a nie wyłącznie relacjonujący je. Po drugie, tytułowa Reka może być traktowana jako realizacja pewnego motywu, powracającego w twórczości różnych, piszących około roku 1920 autorów, których przyjęło się wiązać z nurtem ekspresjonistycznym. Niniejszą interpretację osnuwam wokół wskazanych wątków, odczytując tekst Le-

I Por. L.B. Jennings, Termin ,groteska”, przeł. M.B. Fedewicz, w: Groteska, red. M. Głowiński, Gdańsk 2003, s. 43 i n. 
śmiana w kontekście, który sam zbudował (cykl Pieśni kalekujacycb), oraz w ramach proponowanego przeze mnie kontekstu historycznoliterackiego i estetycznego ${ }^{2}$.

Obecność w wierszu Reka wyraziście zarysowanego pierwszoosobowego podmiotu mówiącego zasygnalizowana zostaje wprawdzie już w pierwszej strofie, ale zabieg ten przeprowadzony jest nader subtelnie. W początkowej zwrotce nie pojawia się bowiem ani jeden czasownik w formie osobowej, który opisywałby aktywność „ja” tekstowego. Wszystkie czasowniki mają formę trzeciej osoby liczby pojedynczej i odnoszą się początkowo do stanu ciała, następnie zaś do działań i stanów tytułowej ręki:

Podczas gdy ciało w mękach żebraczego postu

Kurczyło się jak ochłap wyschłego moczaru,

Ręka ma w samowolnym obłędzie rozrostu

Wszerz i wzwyż potworniała od żądzy bezmiaru.

Wypaczona od skwarów i pusta, jak dzieża,

Miażdżąc stawów hamulce, rosła mi i rosła,

Czując radość zawczasu ciosanego wiosła,

Co już w samym zarodku śni morskie bezbrzeża!3

„Ja" liryczne uobecnia się dla czytającego w dwóch krótkich zaimkach: dzierżawczym („ręka ma”) i osobowym („,rosła mi i rosła”). Na dobrą sprawę, przy pośpiesznej lekturze można by ich obecność po prostu przeoczyć w gęstwinie obrazowych metafor i porównań. Horrendalny wzrost kończyny („obłęd rozrostu”, „potwornienie”, „miażdżenie”) „wypycha” podmiot liryczny poza strofę, unieważnia jego obecność w wierszu i o czym mówi ostatnia strofa - doprowadza go na skraj szaleństwa. W końcu okazuje się bowiem, że ręka nie tylko oderwała się od reszty kurczącego się ciała, ale konsekwencje jej autonomizacji sięgają jeszcze dalej: zagrażają istnieniu podmiotu.

${ }^{2}$ Teza o ekspresjonistycznych elementach w twórczości Leśmiana, zwłaszcza w tomie Łąka, nie jest oczywiście nowa. Jan Józef Lipski dostrzega w balladach Leśmiana „wiele cech pozwalających widzieć w nich realizację tendencji charakterystycznych dla ekspresjonizmu tych lat”. Lipski wskazuje na dwa rodzaje zabiegów wierszowych u Leśmiana, które pozwalają łączyć go z tym nurtem modernizmu: po pierwsze, eksponowanie motywów makabrycznych, wampiryzmu i kalectwa, po drugie zaś - komunionistyczne głoszenie pochwały trudu prostego człowieka. Por. J.J. Lipski, Ekspresjonizm, w: Stownik literatury polskiej XX wieku, red. A. Brodzka et al., Wrocław 1992, s. 267. W niniejszym szkicu próbuję wskazać na - pokrewny pierwszemu z wyodrębnionych zabiegów - inny jeszcze chwyt tekstowy, łączący, jak się wydaje, Leśmiana z głoszonymi przez ekspresjonistów przeświadczeniami antropologicznymi. s. 128.

3 B. Leśmian, Reka, w: idem, Poezje, wybór, wstęp B. Zadura, Lublin 1982, 
Przekroczyła mych kości zbolałe granice,

Przerosła moją duszę, sumienie i łoże,

I lękam się, że skoro ukryję w niej lice,

Nigdy już ich na światy nie wyłonię boże!

Bardzo ludzki, mogący budzić współczucie gest ukrywania twarzy w dłoniach wobec szaleńczego wyolbrzymienia ręki okazuje się zdradziecki. Podmiot rozumie, że wybujała kończyna jest w stanie pochłonąć go w całości, fizycznie unicestwić, odebrać nieopatrznie powierzoną jej w chwili bólu twarz i tożsamość. Jak gdyby tego było mało, ręka, z pomocą której dokonuje się otwierającego modlitwę znaku oddania się w Boską opiekę, w swej groteskowo wyolbrzymionej postaci całkowicie uchyla pierwotny sens tego gestu:

A gdy się nią przeżegnam - przesadny znak krzyża,

Obłąkany rozpędem zbytniego ogromu,

Źdźbłem zaledwo się garnie do mego pobliża,

A resztą - pierzcha w mroki, nie znane nikomu!

Zamykający wiersz (po cytowanej wyżej strofie następuje już tylko refren, powtarzany w tym miejscu po raz trzeci) obraz znaku krzyża, ulegającego dyspersji i unicestwieniu, „rozpierzchnięciu” i odejściu „w mrok”, to obraz zgoła apokaliptyczny. Taki krzyż nie ma mocy zbawczej, nie daje ani ukojenia w życiu ziemskim („przesadny” i „obłąkany” nie może stanowić znaku wyższego sensu ludzkiej egzystencji), ani zbawienia w perspektywie wieczności (ta ostania okazuje się nieoswojoną i groźną ciemnością, do której trafia się w akcie bezładnej „ucieczki do przodu”). Rozrost ręki nie tylko zagraża fizycznej egzystencji podmiotu, ale także uniemożliwia odnalezienie ratunku w religijnym rytuale, nadając mu wraz z pokracznym rozmiarem - błędny wymiar. Od zdeformowanego świata nie ma zatem ucieczki ani w rozpacz, ani w modlitewną ufność.

Postrzeganie i opisywanie człowieka w sposób eksponujący jedną tylko część ciała (tak jak ma to miejsce w wierszu Leśmiana), z jakichś powodów pierwszoplanową, spotkać można często w sztuce ekspresjonistycznej. Dobrym przykładem ilustrującym ów sposób obrazowania stanowi grafika związanego z poznańską grupą Bunt, Artura Marii Swinarskiego, zatytułowana Pijak (1919). Postać ludzka została tu zredukowana do widocznej w centrum pola obrazowego twarzy o ostrych rysach, w której rozpoznać można oczy, nos i usta. Ta szczególna ranga twarzy zostaje potwierdzona przez fakt, że wszystkie pozostałe 


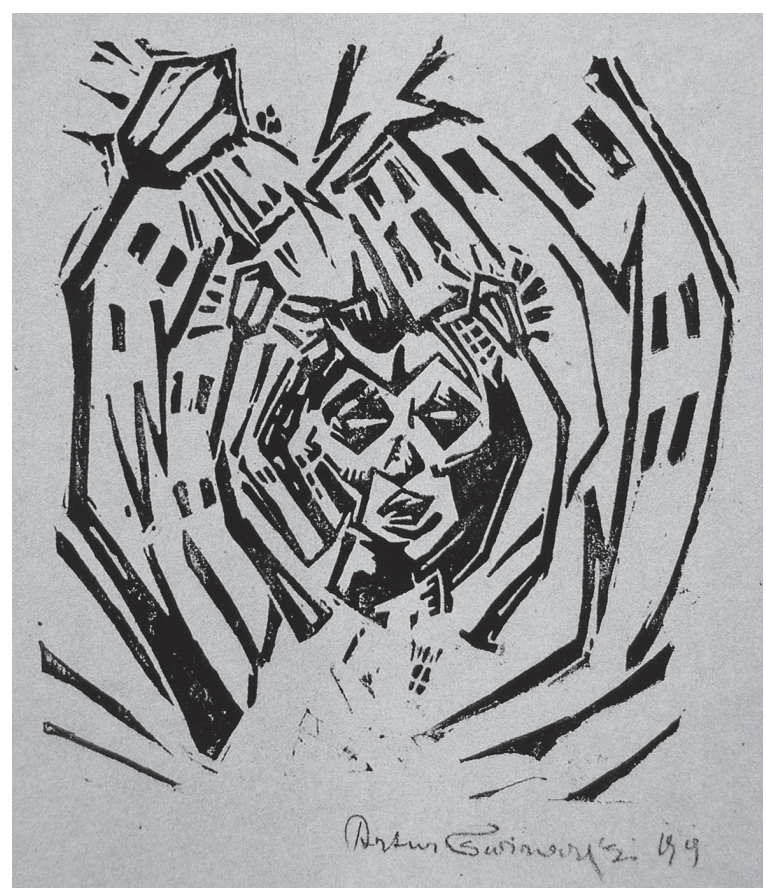

Artur Maria Swinarski, Pijak, linoryt, 1919 (własność Muzeum Narodowego w Poznaniu)

elementy świata przedstawionego wydają się załamywać wokół niej, zmieniając swoje znane $\mathrm{z}$ rzeczywistości ksztalty (ściany domów i latarnie są wygięte, jak gdyby okalają pozostającą $\mathrm{w}$ centrum głowę).

Wracając na grunt literatury, skonstatujmy, że wiersz Stanisława Kubickiego powstały mniej więcej w tym samym czasie co Reka Leśmiana i należący do cyklu Psalmy Noego otwiera następująca fraza:

\section{USTAMI więc tylko i uchem jest Noe ${ }^{4}$.}

W sposób bardziej lapidarny przeprowadzony został tutaj ten sam zabieg, co w pierwszej strofie wiersza Leśmiana: osoba bohatera sprowadzona została do fragmentu jego ciała. Obraz ten można zapewne próbować zobiektywizować jako wyraz bezgranicznej koncentracji Noego na modlitwie i na słuchaniu

4 S. Kubicki, Ustami więc tylko i uchem jest Noe, w: idem, Ein Poet übersetzt sich selbst. Gedichte zwischen 1918-1921 (Poeta thuaczy sam siebie. Wiersze z lat 1918-1921), Berlin 2003, s. 129. Dokładnej daty powstania cyklu Psalmy Noego nie udało się ustalić, choć wiadomo, że został napisany w latach dwujęzycznej fazy twórczości poety, między 1918 a 1921 rokiem. 
słowa Boga, zwiastującego upragniony ląd. Podobnie jak rozrost ręki z wiersza Leśmiana tłumaczyć można żebraczą profesją podmiotu. Przecież obrazy te stają się czymś więcej niż tylko metaforą sytuacji, w jakiej znalazł się bohater wiersza.

Po pierwsze, stanowią sygnał dezintegracji ciała na skutek niebywałego napięcia, często lęku. Kiedy u Leśmiana w ostatniej strofie czytamy wyznanie podmiotu: „lękam się”, jest to jedyny w całym wierszu przykład użycia czasownika w pierwszej osobie liczby pojedynczej, jedyny moment, kiedy podmiot bezpośrednio ujawnia się ze swoim uczuciem, jak można z tego wnioskować - dominującym. Podobnie w wierszu Kubickiego (przykłady w cytowanych niżej fragmentach) emocjonalny stan bohatera to przede wszystkim „obawy” i „bojaźń” - choć zastrzec należy, że w tym przypadku uczucia te wskazują na wymiar egzystencjalny i etyczny (towarzyszą „pytaniom” i „bezradności” Noego), u Leśmiana zaś są związane $\mathrm{z}$ niszczącą działalnością straszliwej ręki.

Po drugie, w liryku zarówno Leśmiana, jak i Kubickiego eksponowanie jednej części ciała jako przedziwnego pars pro toto bohatera jest ściśle związane $\mathrm{z}$ innym zabiegiem podejmowanym przez twórców, mianowicie - osobliwą mediacją między różnymi perspektywami nadawczymi. W wierszu Kubickiego, po cytowanej wyżej frazie i całej partii tekstu mającej charakter opowieści o Noem, następuje quasi-modlitewny zwrot do Araratu (nie wiadomo, czy wygłaszany przez anonimowy podmiot, czy - przez Noego), a w ostatniej strofie - całkiem już jawne przemieszanie nadawczych instancji:

Tyle wieczorów opuszcza się na obawy moje i pytania, niezliczonych snów bojaźń trzęsie bezradnością moją, a żadna odpowiedź nie opada owocem dojrzałym w me łono.

Wędrujemy bezustannie

tam leży Ararat

wybrzmieć to Ararat

wygasnąc to Ararat

wyzwolenie.

W interpretacji Kubickiego wypatrujący lądu biblijny patriarcha, sprowadzony początkowo do „ust” i „ucha”, staje się w końcu przedstawicielem zbiorowości istot skazanych na tę samą kondycję wędrowców. Do tego grona należą wszyscy ludzie (nie tylko więc "ja” nadawcze, ale także „ty” odbiorcze przynależą do zbiorowego „my”), podobnie jak wszystkich ludzi dotyczy biblijna prawda o stworzeniu i grzechu. Dlatego przyjęcie 
przez podmiot mówiący perspektywy „my” w ostatnich wersach utworu wskazuje na przełamanie bolesnego stanu osamotnienia, na który skarżył się wcześniej:

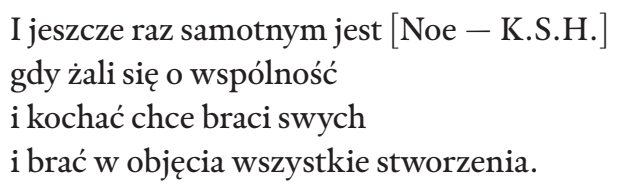

Mediacja między perspektywą ,ja” i „my” w granicach jednego liryku jest zabiegiem stosunkowo częstym w twórczości poznańskich ekspresjonistów, przysparzającym najczęściej znacznych trudności percepcyjnych i nie zawsze naprawdę udanym formalnie (przykładami wiersze Jana Stura Muzyka, Józefa Wittlina Hymn nad bymnami). Wydaje się, że pewien element tego - $\mathrm{w}$ istocie dość szczególnego - zabiegu znaleźć można także w Rece Leśmiana.

Między cytowanymi wyżej pierwszą i ostatnią strofą tego wiersza znajduje się bowiem jeszcze druga strofa, niespodziewanie (choć tylko chwilowo) zmieniająca perspektywę oglądu niezwykłego zjawiska. Wydawać się może, że budzący grozę rozrost ręki da się zażegnać stosownym aktem woli:

My, co mamy dłoń większą nad zamiar człowieka,

Pośpieszniej się od niego lub od niej oddalmy!

Jak odczytać tę frazę: czy jako chwilę trzeźwego rozeznania sytuacji, racjonalizującą złowrogie doświadczenie utraty kontroli nad własnym ciałem, próbę przywrócenia porządku za cenę „oddalenia się” od własnej ręki lub właściwych sobie celów („zamiar człowieka")? Zarysowana alternatywa wskazuje, że sytuacja nie może wrócić do normy, bo ani wyrzeknięcie się tego, co najintymniejsze, bo cielesne, własne, ani tego, co konstytuuje bycie człowiekiem, nie może być dobrym rozwiązaniem.

Mimo to druga strofa stanowi rodzaj retardacji, odsuwa w czasie unicestwienie podmiotu. Opóźnianie nieuniknionego nadejścia katastrofy zbudowane jest przez ciąg wyliczeń w drugiej części strofy, ale przede wszystkim - przez dokonanie przesunięcia w strukturze podmiotu mówiącego. W tej strofie zamiast „ja” pojawia się „my”, które, choć niewolne od zagrożenia ze strony potężnej ręki, swoim pojawieniem się zasadniczo zmienia perspektywę, z której ów problem jest oglądany. Przejściu od „ja” do „my” towarzyszy bowiem nieredukowalne wrażenie intersubiektywizacji przekazywanych treści, nawet wówczas, gdy 
bliższe przyjrzenie się im takie wrażenie niweluje. W pierwszej strofie przytłoczone rosnącą ręką „ja” liryczne skłonni jesteśmy odczytywać jako głos powoli odchodzącego od zmysłów żebraka i tym samym umieszczać bohatera lirycznego $w$ jednym rzędzie $\mathrm{z}$ innymi bohaterami Pieśni kalekujących - ogarniętym obłędem szewczykiem, beznogim nędzarzem, doznającym epifanii kulawym żołnierzem. Druga strofa, rozpoczynająca się zaimkiem „my”, nie pozwala na podobne, bezpieczne zdystansowanie się wobec bohatera, ponieważ poszerza niebezpiecznie zasięg owego szaleństwa i liczbę osób nim ogarniętych. Kolejne wersy zawierają nawet sugestię, że szaleństwo, ogarniające wzrastającą rękę i unicestwiające podmiot, może niejako z natury rzeczy stać się udziałem każdego człowieka - wobec wszystkich ludzi prawdziwe jest bowiem stwierdzenie:

Jakże znikąd przyszliśmy i jakże z daleka,

Że dłoń nasza w świat rzuca nieludzki cień palmy!

Czy „nigdzie” może znajdować się „daleko”? To pytanie wcale nie wykazuje sprzeczności w przedstawionym rozumowaniu, przeciwnie - otwiera drogę ku odczytaniu w wierszu Reka metafizycznych intuicji, wyrosłych na gruncie językowym. Zawieszając ten wątek, dobrze znany czytelnikom Leśmiana, a odróżniający jego dykcję poetycką nie tylko od dzieł ekspresjonistów, pozostańmy przy rozważaniach o naturze podmiotu mówiącego, które są w takim samym stopniu skomplikowane.

Chwiejna, niepewna, rzec by można: utajona, obecność podmiotu mówiącego $\mathrm{w}$ pierwszej strofie $\mathrm{w}$ drugiej zwrotce zastąpiona zostaje prostym przeciwieństwem, gwałtownym ujawnieniem się „my”. Nieusuwalne wrażenie dziwności i w efekcie niejasny status wygłaszanych w drugiej strofie sądów wywołane są konsekwentnym stosowaniem rzeczownika „dłoń” w liczbie pojedynczej i jednoczesnym odnoszeniem go do zbiorowości zarysowanej przez użycie zaimka „my” - zupełnie tak, jak gdyby „dłoń” była jakimś wspólnym dla wszystkich ludzi mianownikiem. W efekcie jednak owa (wspólna) dłoń okazuje się rzeczywiście „nieludzka” (ponad-ludzka, ponad-człowiecza, przekraczająca ramy pojedynczego ludzkiego istnienia), wskazuje bowiem na jakiś rodzaj wspólnotowości, wyrastający ponad to, co da się powiedzieć o jednostkowej egzystencji. Podczas gdy kiedyś, być może, czymś takim była ludzka dusza, jednocześnie własna, ale i wskazująca na wspólnotę duchową wszystkich ludzi (do której zdaje się odwoływać w swoim psalmie Kubicki), w cytowanym wierszu do roli tej powołana zostaje wyrosła nad 
miarę ręka, unaoczniając wszelkie sprzeczności takiego zarazem jednostkowego i ponadjednostkowego traktowania.

Jeśli wcześniej jeszcze można było sądzić, że w balladzie opowiedziana zostanie historia przerażającej autonomizacji materii, mająca wszelako rangę osobliwości i jednostkowego przypadku, to druga strofa uzmysławia odbiorcy, że on także - przynajmniej potencjalnie - może doświadczyć podobnych wydarzeń na własnej skórze. Groteska przestaje podważać jedynie istnienie racjonalnie wytłumaczalnej rzeczywistości przez wskazanie niedającej się wyjaśnić sytuacji. Od tego momentu wiersz, wciągając $\mathrm{w}$ obręb przerażających wydarzeń osobę odbiorcy, uświadamia mu, że nie może on bezpiecznie sytuować się na zewnątrz opisywanych okropieństw. Takie wykorzystanie elementów groteski odróżnia komentowany utwór od pozostałych Pieśni kalekują$c y c h, \mathrm{w}$ żadnej z nich nie został przeprowadzony podobnego rodzaju atak na autonomię czytelnika i jego przywiązanie do myśli o własnej przynależności do sfery tego, co normalne. W innych balladach $\mathrm{z}$ tego cyklu zarówno narrator, jak i czytelnik znajdują się w istocie poza światem przedstawionym, co sprawia, że opisywane przypadki kalectwa budzą grozę, ale i współczucie, niekiedy (jak przy lekturze wiersza Żotnierz) zabarwione nawet odcieniem rozbawienia. Ballada Reka, w której między bohaterami a czytelnikiem nie pośredniczy wszechwiedzący narrator, a zdarzenia poznajemy dzięki uczestniczącej w nich osobie żebraka, operuje podwójnym skrótem perspektywy: redukcji ulega (względem innych Pieśni kalekujacych) dystans narracji trzecioosobowej do pierwszoosobowej, następnie zaś (w obrębie tekstu) zniwelowana zostaje odległość między „ja” nadawczym a odbiorcą przez wprowadzenie nadawczego „my”.

Mimo szkicowego jedynie sygnalizowania własnej obecności i próby ukrywania się pod zbiorowym „my” podmiot mówiący w tym wierszu nie ma nic wspólnego z ,niewidocznym” narratorem-komentatorem, opowiadającym o tajemniczych i tragikomicznych zdarzeniach, jakich dotyczy fabuła wierszy Zaloty, Szewczyk, Garbus i Żotnierz. To przez jego mentalnie skrzywioną perspektywę, która nagle ulega rozszerzeniu z „ja” do „my”, czytelnik postrzega rzeczywistość przedstawioną i tym samym zostaje wciągnięty do partycypowania w świecie, który w istocie jest światem wrogim i obcym, takim, jaki obawiamy się, że mógłby być, nie zaś takim, jaki jest nam znany ${ }^{5}$. Doprawdy, sytuacja odbiorcy tego liryku nie jest prosta: od pierwszych słów wiersza

5 Por. B. McElroy, Groteska ijej wespótczesna odmiana, przeł. M.B. Fedewicz, w: Groteska, red. M. Głowiński, Gdańsk 2003, s. 132. 
czytelnikowi towarzyszy wątpliwość poznawcza, niepewność co do statusu opisywanych, groteskowych zdarzeń. Próba uchylenia ich przez przypisanie podmiotowi mówiącemu szaleństwa nie udaje się, gdyż odbiorca zastaje nolens volens wciągnięty do przedziwnej z nim wspólnoty.

Jeśli wrócimy na chwilę do grafiki Swinarskiego, okaże się, że i w dziele plastycznym uskuteczniona została dość przewrotna gra z odbiorcą. Dlaczego bowiem to nie bohater - tytułowy Pijak, lecz my, widzowie, postrzegamy świat jako powyginany i krzywy, kręcący się wokół głowy nieznajomego? Czy i tu nie zostaje ustanowiona - innymi, właściwymi plastyce środka$\mathrm{mi}$ - dziwna wspólnota między bohaterem a widzem, do której widz zostaje zaanektowany bez pytania, zmuszony do uczestnictwa w delirium postaci?

W komentowanym wierszu wyróżnić można trzeci jeszcze, prócz pierwszoosobowego w liczbie pojedynczej i mnogiej, sposób mówienia podmiotu tekstowego, mianowicie całkowicie bezosobowy, uchylający pytanie o nadawcę wobec mocnego dookreślenia adresata. Ujawnia się on $\mathrm{w}$ refrenie, powtarzanym trzykrotnie:

Ręko, nadmierna ręko,

W pięść modlitewną się złóż!

Męko, nadmierna męko,

Zmalej i skurcz się i znuż!

Trudno oprzeć się wrażeniu, że refren pełnić ma funkcję nie tyle zaklęcia rzeczywistości (na co wskazuje jego formalny kształt - mamy do czynienia $\mathrm{z}$ dwuelementową sekwencją rozkaźników), ile raczej dodatkowego skomplikowania sytuacji przedstawionej. Dopiero ta część tekstu pozwala dostrzec w całej wyrazistości dziwność używania w całym wierszu liczby pojedynczej wyrazu „ręka”. Stosowanie liczby pojedynczej w odniesieniu do rzeczowników, które w rzeczywistości pozatekstowej występują parami, zawsze przynosi efekt szczególny - niejakiej abstrakcjonizacji opisywanego fenomenu; proces ten, widoczny $\mathrm{w}$ wierszu Leśmiana, w refrenie osiąga apogeum, przypieczętowuje niejako nienaturalność tytułowej kończyny. Obraz jednej ręki złożonej do modlitwy to wszak obraz niemożliwy; do złożenia rąk potrzebne są bowiem dwie ręce. Może dlatego mowa jest w refrenie o „modlitewnej pięści” - zwinąć się w kułak potrafi bowiem także jedna dłoń. Tym samym przecież treść zaklęcia ulega ostatecznemu rozkładowi, jest bowiem zarazem prośbą o modlitwę i namową do gestu wręcz przeciwnego: zaciśnięcie 
pięści może oznaczać różne stany i emocje, wszystkie jednak krańcowo odległe od modlitewnego wyciszenia i spokoju. Nawet jeśli skojarzyć opisywany ruch z gestem pokutnym, towarzyszącym słowom mea culpa, sformułowanie „pięść modlitewna” trudno jest uznać za niesprzeczne. Refren wiersza pęka, spinany w całość wyłącznie nachalnym rytmem, niemożliwy do zrozumienia, tak jak niemożliwa do ogarnięcia jest cała opisywana w liryku sytuacja. Reka to pieśń wewnętrznie popękana, prawdziwie kaleka, utrzymywana w całości i ratowana przed „rozpierzchnięciem w mrok" wyłącznie gorsetem formy.

W Pieśniach kalekujacych nie tylko ręka, ale także garb rozrasta się ponad miarę, tłamsząc i unicestwiając ludzkie istnienia. $\mathrm{O}$ ile jednak garb jest zawsze, kiedy tylko się pojawia, deformacją i źródłem zaskoczenia, także w rzeczywistości pozatekstowej, o tyle ręka, aby była groźna, musi zostać w odpowiedni sposób zobaczona. Nie wystarcza tu chyba najprostsze z pozoru wyjaśnienie, o którym była mowa już wcześniej - że tytułowa kończyna to oczywisty atrybut żebraka. Przecież już w refrenie mowa jest o innych niżżebracza funkcjach ręki: opisane są tu dłonie złożone do modlitwy, ale i dłoń zwinięta w pięść, wygrażają$\mathrm{ca}-$ dziwnie zlane w jedno. Wydaje się, że ręka ulega w wierszu Leśmiana emancypacji ze względu na tkwiącą w niej wyjątkową potencjalność. Żadna inna część ciała nie jest podmiotem tak wielu czynności, żadna też - prócz może twarzy i oczu - nie ma takiej siły wyrażania emocji, nie jest w działaniu i ekspresji tak samodzielna. Może istotnie „śnić morskie bezbrzeża”, bo zwłaszcza w sytuacji nadmiernego wzrostu - może ona prawie wszystko.

Taka wszechmocność ręki przywodzi na myśl wiersz innego autora, powstały i ogłoszony w tym samym roku, w którym wydany został tom Łąka, mianowicie O rękach Józefa Wittlina (z tomu Hymny, 1920). Pisze Wittlin w swojej „pieśni uwielbienia":

O ręce, ręce, szczodrobliwe ręce!

O ręce, ręce, pracowite ręce!

O ręce: dwa żywe przekleństwa! ${ }^{6}$

Zdumienie rękami w wierszu Wittlina nie ma źródła ani w ich nienaturalnej deformacji, ani też w sztuczności, wywołanej wielokrotnym użyciem słowa „ręka” w liczbie pojedynczej. Wynika

${ }^{6}$ J. Wittlin, O rękach, w: idem, Hymny, Poznań 1920, s. 41. 
z obserwacji rzeczywistości i ludzkich zachowań, których metonimią stają się ręce:

O ręce - kije, o ręce - lopaty,

O dłonie - serca, palce - poematy!

$[\ldots]$

Grabie do zgarniań błyszczących kup złota, różdżki, spod których powstaje tęsknota, gdy obudzacie nieme, martwe struny - $[\ldots]$

Wy - które zbrodniarze kaszą, by wami spełniać najstraszliwsze mordy! Wy, co wznosicie miasta i świątynie! Wy, co burzycie miasta i świątynie i Bogu złotą kowacie koronę!

- Mojemi usty bądźcie pochwalone!

Rzeczywisty bohater wiersza to „milion rąk”, którego obserwowanie napawa podmiot wiersza zarazem zachwytem i przerażeniem. Podobnie jak w innym z Wittlinowskich dzieł, w tekście Ballada-bymn, różnorodność świata staje się źródłem zachłyśnięcia nim, niewyczerpanej żywiołowości i aktywizmu:

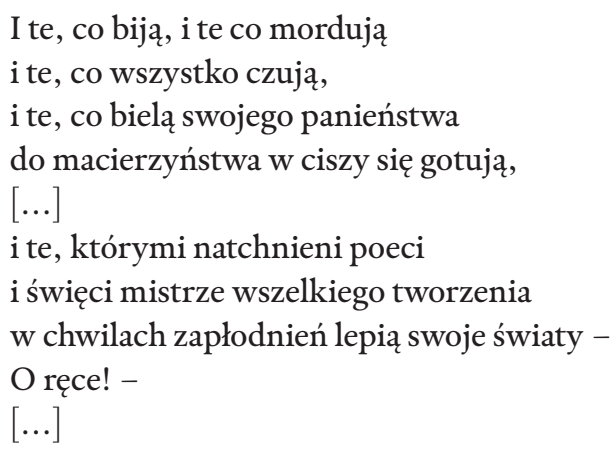

W hymnie O rękach wyrażone zostało coś więcej niż tylko pochwała różnorodności stworzenia. Opisywane skrajności (morderstwa i bohaterstwa, grabieże i twórczość artystyczna), jakie charakteryzują działania „rąk”, przypominają nieco leśmianowską, oksymoroniczną „pięść modlitewną”. Intensywna część laudacyjna wiersza Wittlina poprzedza finałowe diminuendo, $\mathrm{z}$ powtarzanym apelem i intensywnym, choć wyciszonym, wyznaniem: 
- Mów ciszej -

W ślad za mną zawsze idzie widmo rąk -

- mów ciszej -

W ślad za mną zawsze sunie widmo lęk.

Ta właśnie nuta zatrwożenia światem z całą jego ujmującą różnorodnością i wszystkimi możliwościami, które niesie, popycha Wittlina i innych pisarzy-ekspresjonistów w stronę refleksji etycznej. Obserwując rzeczywistość z najbardziej własnego punktu widzenia, starają się oni zazwyczaj wydawać wyroki o charakterze uniwersalizującym i dawać jednoznaczne wskazówki moralne (co zresztą najczęściej prowadzi do oczywistej sprzeczności i wielkich oporów wysłowienia - trzeba stwierdzić, że uroda Wittlinowskich fraz nie znajduje równej sobie w obrębie polskiej poezji ekspresjonistycznej). Wierzą ponadto w prymat duchowego wymiaru rzeczywistości nad jej stroną fizyczną. W tym właśnie miejscu definitywnie rozchodzą się drogi poezji ekspresjonistycznej i dzieła Bolesława Leśmiana. W wierszach autora $Ł a k i$ dziwność istnienia jest tematem najpierwszym, pozostawia wszelako człowieka zaskoczonego, bezradnego i samotnego, niekiedy nawet (jak w większości Pieśni kalekujacych) zdystansowanego wobec niej, a świat fizyczny zawsze zwycięża w konfrontacji z tym, co duchowe. Dlatego Leśmianowski rym dla słowa „ręka” brzmi „męka”, podczas gdy Wittlin proponuje opalizującą innymi zupełnie znaczeniami parę „rąk” - „lęk”. Materia jest w poezji Leśmiana żywiołem złowrogim, bo sprowadzającym człowieka do własnych, fizycznych wymiarów. Dla ekspresjonistów bywa ona najczęściej źródłem nieustannego niepokoju, z którego jednak rodzi się to, co autentyczne - duchowość.

Mimo tych zastrzeżeń wydaje się, że wiersz Reka sytuuje się gdzieś w połowie drogi między najczęstszym dla Leśmiana sposobem pisania a ekspresjonistycznym wariantem poezji, $\mathrm{z}$ właściwym mu etyzmem, rozbiciem podmiotu oraz poszukiwaniem wspólnoty. Wskazuje na to, że nie każde posłużenie się przez poetę „deformacją" jednoznacznie odsyła w kierunku ekspresjonizmu, ale także pozwala uzmysłowić sobie, że coś z istoty poezji tego nurtu - problematyka podmiotu, przede wszystkim zaś egzystencjalna „trwoga”, a nie tylko „zdziwienie” - było na początku lat dwudziestych w poezji polskiej istotne. 
KATARZYNA SZEWCZYK-HAAKE

\section{Crippled song. Reka by Bolesław Leśmian within the context of expressionistic poetry}

The analysis of Leśmian's poem Reka (from the collection of poems entitled $Ł a k a, 1920$ ) leads to distinguishing certain features of the poem that make a connection of the poem with literary expressionism feasible. The above similarities can be testified not only by distinct macabre motifs but also a very peculiar way the narrator constructs his narrative that can be concluded as an attempt at establishing a particular bond between the protagonist and the reader. Works written by the Poznańbased expressionists Stanisław Kubicki and Józef Wittlin provide the appropriate context for the poem.

KATARZYNA SZEWCZYK-HAAKE - dr, historyczka literatury, thumaczka, pracownik naukowy Uniwersytetu Adama Mickiewicza w Poznaniu. Autorka książki Poezja Emila Zegadłowicza wobec światopoglądowego i estetycznego projektu ekspresjonizmu (Kraków 2008).

e-mail: haaczyk@amu.edu.pl 
